\title{
Refining and disseminating site-specific nutrient management technology in Thailand
}

\author{
Tasnee AtTAnAndanA ${ }^{1}$, Prateep VerapattananiRund ${ }^{2}$, Russell Yost $^{3 *}$ \\ ${ }^{1}$ Department of Soil Science, Kasetsart University, 50 Phaholyothin Road, Jatujak, Bangkok 10900, Thailand \\ ${ }^{2}$ Eco-Community Vigor Foundation, Bangkok, Thailand \\ ${ }^{3}$ Department of Tropical Plant and Soil Science, University of Hawai 'i at Manoa, 3190 Maile Way, Honolulu, HI, 96822
}

(Accepted 7 January 2008)

\begin{abstract}
The development of site-specific nutrient management technology for maize in Thailand began in 1997. The site-specific nutrient management technology was simplified by using soil test kits in the field, field identification of soil series and subsequent referencing of soil properties by soil series, and by organizing and developing a site-specific recommendation with a decision aid. The second aspect of the conceptual approach was not only to simplify the technology but also to empower and build farmer capacity. The dissemination process was modified in 2002 to increase farmer empowerment by identifying and empowering farmer leaders. The two main components: (1) simplifying the agricultural technology and (2) building farmer capacity resulted in higher maize yields and profit by the farmers. Increased self-reliance, a better standard of living, more knowledge of crop production, soil improvement and networking of the farmer associations were all observed. The SimCorn software was developed to aid decision-making by providing on-site calculations of the Nitrogen, Phosphorus and Potassium (NPK) fertilizer recommendations using soil series identification and soil test kit results. Assistance in calculating the bulk blending of fertilizer was also given in the software. Techniques designed to empower farmers were tested and found to be effective. These techniques included social mapping to identify farmer leaders, sharing knowledge, knowledge capture and management, and scaling up of the improved knowledge and capability. Farmer leaders learned to implement site-specific nutrient management and to disseminate the technology to other farmers in their community. The farmer leaders obtained not only better income but improved soil and water management for sustainable agriculture. The technology was initially developed for maize production systems but was extended to rice and sugarcane farmer leaders as well.
\end{abstract}

site-specific nutrient management / maize / rice / sugarcane / dissemination of technology / empowerment / capacity building

\section{INTRODUCTION}

The revolution in management of crop nutrients and fertilizers has become very apparent for both environmental and economic reasons in developed countries. These concerns and issues are even more pressing in developing countries of the tropics, where nutrient mining and impoverishment are widespread (Smaling and Braun, 1996). Clearly, there is a need to manage nutrients in food production systems more precisely, to ensure increased food production, but also to ensure reduced environmental degradation. The concepts of Precision Agriculture were developed out of such needs, but as applied in developed nations have come to imply a high level of technology. In the tropics of developing countries where the farms are small, the technologically advanced methods of Precision Agriculture cannot be applied wholesale due to the exceedingly small units of production, but also due to the lack of mechanized, high-tech equipment needed to support the usual high-tech methods. The average farm size in Thailand, for example, is about 3.2-6.4 ha (Department of Agricultural Extension, 2002) Another important factor that limits the application of traditional Precision Agriculture concepts is the inadequate means of obtaining the quantitative data typically required by GIS systems and geospatial analysis. In particular, the lack of or limited access to soil-testing laboratories is the norm in most countries of the tropics. As a consequence, fertilizer recommendations for most crops remain a blanket fertilizer recommendation - one size fits all - given to farmers through government-financed extension officers. The need to adapt to and adjust for specific conditions is not realized and not possible. As a result, the extension process often fails and results in more poverty for the farmers and often increased wealth of the middle man who is selling agricultural inputs at high prices and buying the output of the farmers at below-market prices.

* Corresponding author: rsyost@hawaii.edu 


\subsection{Development of the site-specific nutrient management technology}

The above was roughly the situation leading to efforts to develop the site-specific nutrient management approach at Kasetsart University, Thailand, in 1997. A methodology of site-specific fertilizer recommendation appropriate for small farms in the tropics was developed using maize as the pilot crop (Attanandana et al., 2007). The technology has evolved in several steps and several components. Initial efforts began with a simplified version of the soil test kit, which would enable extension officers to carry out soil test analysis in the absence or unavailability of soil test laboratories. Following the logical process of Data $\rightarrow$ Interpretation $\rightarrow$ Recommendation, it soon became apparent that the soil test kit results needed the soil property information in order to predict nutrient status and behavior. This led to the development of the withinfield soil series identification key (Boonsompopphan and Vearasilp, personal communication, 2002). With the gathering of the soil property information it became apparent that a consistent method of assembling these data in a knowledgeable way was needed. This realization resulted in the development of a decision aid called SimCorn (Attanandana et al., 2006). This computer program permitted the bringing together of the soil test kit results, the pertinent soil series information, the crop cultivar specification and the type of fertilizer, to develop a fertilizer recommendation. These three tools comprised the site-specific technology as of 2002 and 2003 (Attanandana et al., 2007). In this way, the traditional technology was greatly simplified, enabling extension officers to learn and carry out the procedures. Early results indicated that there remained a missing element to the technology. In addition to simplifying the technology, it was apparent that it was also necessary to increase the awareness and capability of those who were to apply it - the farmers. Discussions began with one of the authors of this manuscript (P.V.), who had extensive experience of working with farmers and farmer empowerment. Thus, the second component of the technology was added - that of farmer empowerment.

\subsection{Involving farmers in technology development}

Involvement of farmers in technology development has been the topic of developmental research for many years. Most of the initial studies took place outside of the US, including Africa (Norman, 1980), Central America (Hildebrand, 1979), South America (Rhoades, 1982) and Southeast Asia (Philippines: Sajise, 1981; Indonesia: Colfer, 1983; Thailand: KKU, 1987), Korten, 1980. Some of the initial studies were summarized under the rubric of farming systems research and development, which was the title of a summary work published by Shaner et al. (1982). Much of the early experience and technique was how to contact and learn from farmers and how to conduct experiments on their farms. Hart (2000) pointed out that the original farming systems approach was extended in three ways: (1) expansion of target systems from cropping systems to whole-farm systems and watersheds; (2) expansion of evaluation criteria - from productivity in early systems to stability and sustainability in later years, and (3) expansion in target populations from small farmers to women, urban poor as well as rural poor, and benefits for future generations. A summary of attempts to widely implement the farming systems approach by Merrill-Sands and Collion (1994) concluded that the major reason for the relatively poor adoption was insufficient attention to the political and institutional dimensions of developing client-responsive research. The authors added that increasing farmer participation in research planning and prioritization is a promising development, but that increased influence and power of farmer organizations would likely be required in the long term. In short, these authors generally advocate empowering farmers to control their own destiny.

Narayan (2007) defines and summarizes empowerment as follows: "Broadly speaking, empowerment refers to the expansion of assets and capabilities of poor people to participate in, negotiate with, influence, control, and hold accountable institutions that affect people's lives." He goes on to suggest that there have been thousands of strategies to empower, but that essentially all of them include at least four actions:

- increased access to information,

- inclusion and participation,

- greater accountability of responsible organizations,

- increased local organizational capacity.

The site-specific nutrient management technology described in this paper, interestingly enough, includes components and activities that address nearly all of Narayan's actions included in empowerment.

One of the most powerful techniques of improving farmer success is that of increasing their self-confidence and convincing the farmers that they have knowledge that is useful and that, if they use it correctly, they can change critical factors of production. The techniques of capacity building were designed to encourage farmers to become aware of their potential and how to use it.

\subsection{Fertilizer use in Thailand}

Thailand imported 3.5 million tons of chemical fertilizer in 2002 which cost about US \$ 523 million, most of which was used on irrigated rice (Department of Agriculture, 2003). There are about 10.4 million hectares of rice in Thailand (Office of Agricultural Economics, 2002) of which only 12\% of land is used for irrigated rice in the dry season (Royal Irrigation Department, 2003). Farmers grow 2-3 crops of rice per year in this area. About one-half of the rice production in the country comes from the irrigated area. The average yield of dry-season rice is about $4280 \mathrm{~kg} / \mathrm{ha}$ (Office of Agricultural Economics, 2002). Blanket NPK fertilizer recommendations have been used by the farmers. To produce one ton of rice, the nutrient requirements of $\mathrm{N}, \mathrm{P}$ and $\mathrm{K}$ are 19,5 and $36 \mathrm{~kg}$, respectively (Yoshida, 1981). The current recommended fertilizer for rice is high in phosphorus $(\mathrm{P})$ content, which has 
resulted in an excess of $\mathrm{P}$ in the soils. Moreover, the overuse of nitrogen $(\mathrm{N})$ fertilizer has resulted in lodging of rice.

The area of sugarcane is about one million hectares, with an average yield of 50-56 ton/ha (Office of Agricultural Economics, 2002). The sugar factories produce about 5.4-6.0 million tons of sugar and more than 3 million tons is exported yearly. The low average yield of sugarcane is due to the rainfed conditions and lack of knowledge of soil and fertilizer management (Department of Land Development, 1991).

The purpose of this paper is to chronicle the development of the site-specific nutrient management technology and report the successful dissemination efforts that both lead to improvements in the technology and illustrate the benefits from the combined approach of simplifying the technology and empowering farmers.

\section{DISSEMINATING SITE-SPECIFIC NUTRIENT MANAGEMENT}

While the essential elements of site-specific nutrient management are described as indicated above, there were refinements and enhancements that have gradually led to the current approach. We briefly describe the initial failures and describe the refinements and the current steps in the farmer empowerment process.

\subsection{Failure of the initial dissemination of technology}

An analysis from the first period of the training in 2001 indicated that most of the farmers did not follow our technology on site-specific nutrient management for maize even after training. This lack of adoption seems to happen with much extension work. The failure of the extension process probably was the result of the following:

1. No opportunity was given for the farmers to share visions with the researchers.

2. All farmers were given the same blueprint recommendation based on fragmented, often stereotyped information about the farmers.

3. The diversity of farmers and localities was not considered in the technology. We could see the data on more debt of the farmers in the newspaper (Manager newspaper, 2005).

\subsection{Empowerment of the farmer leaders}

Empowerment of the farmer leaders was initially carried out through techniques described by Attanandana et al. (2004). In this approach, farmers were asked three questions: (1) how many hectares of maize are grown in the village, (2) what are the costs of production, yields and crop prices on the local market, and (3) who is the best maize farmer in the village and why? Farmer leaders were selected from those who obtained and presented this information at subsequent meetings. Farmer leaders were subsequently trained in the components of the simplified site-specific nutrient management technology. The initial capacity building included: focus on self-reliance, farmer-centered and balanced development, participation of farmers, interactive learning through action and the establishment of farmer networks.

The empowerment approach was further developed and tested after further dissemination. The approach includes the following steps:

- Social mapping - Identifying the farmer leaders with the best practice in the community.

- Sharing and learning - The sharing and learning of the information and expertise of the farmer leaders identified by social mapping in relation to their best practices.

- Conducting experiments and carrying out research - This is the action research step, whereby the information and expertise of the farmer leaders is tested in practice. It is planned and carried out in field plots in real situations by the farmer leaders themselves. The farmers who had been selected and trained in the empowerment techniques subsequently carried out the field tests and dissemination.

- Knowledge capture - This step emphasizes the documentation of the knowledge captured from sharing and learning of the result of the action research carried out in the previous step.

- Knowledge management - This step is the explicit sharing of the combined expertise of the farmer leaders and the research carried out in the field in the above steps. It represents probably the best available information as a synthesis of past experience and new data to develop a new, appropriate model.

- Upscaling - This step represents the combining of the best available information in the previous steps into a type of role model or example approach taken by some of the farmer leaders in combining their experience with new, field research results.

While the above process appears to be quite linear it, in fact, is not, as there might be a combination of one or more of the steps occurring simultaneously or at various times in the capacity-building process.

Action research by farmers was encouraged in the current project on maize, rice and sugarcane and was taught to the farmers and researchers. Farmers were encouraged to plan and conduct field experiments with advice and assistance from farmer leaders and local researchers. After they learned the results of field tests, the farmers used the appropriate fertilizer on maize, rice and sugarcane in the demonstration plots, where a great deal of learning takes place and where other farmers learn about the technology.

\subsection{Dissemination of the technology}

The site-specific nutrient management technology was transferred to the farmers after they completed the empowerment exercises. The farmer leaders disseminated the knowledge to the other farmers. The fertilizer recommendation handbook, soil series identification guidebook, soil test kit, and the decision-aid software of soil series identification and NPK 
Table I. Economic analysis of the yield, investment and profit of the site-specific nutrient management and farmers' plots in four provinces (comparison between fertilizer management methods) in the year 2003.

\begin{tabular}{|c|c|c|c|c|c|c|c|}
\hline \multirow{2}{*}{ Province } & \multirow{2}{*}{ No. of comparisons } & \multicolumn{2}{|c|}{ Yield (kg/ha) } & \multicolumn{2}{|c|}{ Investment (US \$/ha) } & \multicolumn{2}{|c|}{ Profit (US \$/ha) } \\
\hline & & Farmer 1 & Site-specific 2 & Farmer 1 & Site-specific 2 & Farmer 1 & Site-specific 2 \\
\hline Average & 248 & $4679 \mathrm{~b}$ & $6327 \mathrm{a}$ & $406.8 \mathrm{a}$ & $406.0 \mathrm{a}$ & $84.5 \mathrm{~b}$ & $258.3 \mathrm{a}$ \\
\hline Nakhon Ratchasima & 89 & $5071 \mathrm{~b}$ & $7192 \mathrm{a}$ & $417.8 \mathrm{a}$ & $396.5 \mathrm{a}$ & $114.7 \mathrm{~b}$ & $358.7 \mathrm{a}$ \\
\hline Nakhon Sawan & 6 & $4732 \mathrm{~b}$ & $4626 \mathrm{~b}$ & $381.0 \mathrm{a}$ & $404.9 \mathrm{a}$ & $115.9 \mathrm{~b}$ & $80.8 \mathrm{~b}$ \\
\hline Lop Buri & 101 & $4263 \mathrm{~b}$ & $5877 \mathrm{a}$ & $402.3 \mathrm{a}$ & $406.4 \mathrm{a}$ & $45.3 \mathrm{~b}$ & $210.7 \mathrm{a}$ \\
\hline Petchabun & 52 & $4809 \mathrm{~b}$ & $5917 \mathrm{a}$ & $399.8 \mathrm{~b}$ & $421.6 \mathrm{a}$ & $105.1 \mathrm{~b}$ & $199.7 \mathrm{a}$ \\
\hline
\end{tabular}

1 Neighboring farmers not using site-specific nutrient management.

2 Site-specific nutrient management plot.

3 Letters show the statistical comparisons between site-specific nutrient management and farmer practice (no site-specific recommendation). Similar letters indicate no difference between the two methods at the $99 \%$ significance level. Maize price was US \$ $105 / \mathrm{metric}$ ton.

fertilizer recommendation were the apparatus and equipment used in increasing the capacity of the farmer leaders. All of the devices were used by the farmer leaders, in turn, for the dissemination process to the other farmers.

\subsection{Expanding the work on rice and sugarcane}

The same concept and dissemination process were extended to rice farmers in five provinces and sugarcane farmers in one province. The project was supported by the Thailand Research Fund (TRF) and Soil Management Collaborative Research Project (SM-CRSP). The work started by simulation of the NPK fertilizer recommendation for rice and sugarcane in the specified provinces using DSSAT (Decision Support System for Agrotechnology Transfer) and PDSS (Phosphorus and Potassium Decision Support System) software for N and PK fertilizer, respectively. Empowerment techniques as described above were used to identify farmer leaders in rice and sugarcane production. A new soil series identification of paddy soil was developed by Dr. B. Bonsoppnan (2008, in preparation). Soil series identification was done on the farmer leaders' land with the visual guidebook for each province. The experimental sites were set up and the different nutrient levels were tested in each site with the farmers as the main actors while the local farmer leaders or officers acted as supervisors.

\section{RESULTS AND DISCUSSION}

\subsection{Dissemination of the technology in 2001}

The technology was transferred to 200 maize farmers and 200 extension officers in 10 provinces with the support of the Department of Agricultural Extension (DOAE). The feedback after training was that not many of the farmers could follow the technology due to many problems, e.g. debt, no fertilizer materials, fertilizer applicators that were not adjustable, etc.

\subsection{Dissemination of the technology in 2002}

The Department of Agricultural Extension and the Thailand Research Fund organized a Fertilizer Revolution Day in
Nakhon Ratchasima province in May 2002. About 300 farmer leaders from many provinces of maize production areas joined the event. A lecture on site-specific nutrient management was presented. A panel of researchers, extension officers, fertilizer company representatives and farmers discussed fertilizer use and the revolution in the way of thinking such that farmers gain confidence and self-reliance for their benefit. The farmers should test the nutrient status in the soils and learn the names (soil series) of the soils in their land. The soil test kits and in-field soil series identification were demonstrated. Mass media, including television and newspapers, joined the event. The field observation of site-specific nutrient management treatments and field results were part of the event. Newspapers published articles about the technology (Khaosod newspaper, 2002). A few months after the event, there was an interview of the maize farmers about the impact of the site-specific nutrient management technology. Some farmers mentioned that the maize yield increased with decreasing fertilizer application when they analyzed the soils using the soil test kit. The soil improvement from our training course resulted in the reduction of production costs (Thairath newspaper, 2002).

\subsection{Dissemination of the technology in 2002-2004}

The further training of 67 farmer leaders and 26 extension officers in 4 key provinces of the maize belt was done with the support of the Food and Agricultural Organization of the United Nations (FAO) and (SM-CRSP) projects. The empowerment techniques were used to select and train farmer leaders. Sixty-seven farmer leaders disseminated the technology to 629 farmers. About 338 farmers had planted maize using sitespecific nutrient management technology. The results showed a marked increase in yield and profit compared with the neighboring farmers' plots (Tab. I).

The impact of transferring the technology for 5 years resulted in benefits to the trained farmers. The economic benefits, shown in Tables II, III, IV and V, were obtained from the maize farmers. The other benefits were obtained by maize, rice and sugarcane farmers. The impact on maize farmers was greater, probably because we have worked longer with them. In the case of rice and sugarcane, after only one year of work, we have gradually empowered them. 
Table II. Comparison of maize yields achieved by site-specific nutrient management (2001-2003) and current practices of the farmers in Nakhon Ratchasima province (2000).

\begin{tabular}{lc}
\hline Method & Yield $(\mathrm{kg} / \mathrm{ha})$ \\
\hline Farmer 1 & $4354 \mathrm{~b}$ \\
Site-specific 2 & $5937 \mathrm{a}$ \\
Year & \\
2000 & $4354 \mathrm{c}$ \\
2001 & $5146 \mathrm{~b}$ \\
2002 & $5739 \mathrm{~b}$ \\
2003 & $6927 \mathrm{a}$ \\
\hline
\end{tabular}

Table III. Yield, profit and cost of maize production where sitespecific nutrient management was applied and the neighboring plots in Nakhon Ratchasima province in 2003 (average of 5 farmers).

\begin{tabular}{lccc}
\hline Method & $\begin{array}{c}\text { Yield } \\
(\mathrm{kg} / \mathrm{ha})\end{array}$ & $\begin{array}{c}\text { Cost of production } \\
(\mathrm{US} \$ / \mathrm{T})\end{array}$ & $\begin{array}{c}\text { Profit } \\
(\mathrm{US} \$ / \mathrm{ha})\end{array}$ \\
\hline Farmer 1 & $5742 \mathrm{~b}$ & $74.6 \mathrm{a}$ & $129.7 \mathrm{~b}$ \\
Site-specific 2 & $8773 \mathrm{a}$ & $51.2 \mathrm{a}$ & $368.3 \mathrm{a}$ \\
\hline
\end{tabular}

\subsection{Benefits from site-specific nutrient management}

1. Economic benefits. The maize yield and profit of the farmers who used site-specific nutrient management were markedly higher than the neighboring farmers who did not use the technology. Tables II-IV showed the consecutively increased benefits from 2001-2004 with the site-specific nutrient management practice.

2. Way of life. The results of farmer empowerment techniques increased confidence and self-reliance and had an impact on the social interactions and welfare of the farmers. This was observed from the previous work on maize and could be noted in the current extension to rice and sugarcane production systems. As Narayan (2007) suggested, we found that empowerment of the farmers was essential for achieving a balance in the economic, social and environmental development goals and to enhance sustainable rural development. Observations and discussions with trained farmer leaders indicated that they, indeed, were changing their way of life. They changed their habits by recording the cost of production, diversifying their cropping, changing their responsibility and being good people. In this way, they had more income and the income was better distributed because of crop diversification. Moreover, they organized and built an organic fertilizer plant in their community. They are happy to teach the neighbors what they learned and received from the project. They are more self-reliant and want to help others.

3. Network of the farmers. The farmers have formed associations and are sharing their resources, e.g. labor, knowledge and assistance. From an interview with a farmer leader who is the president of the maize association, we learned that the farmer organization now comprises about 15000 members from 11 provinces in the North, Northeast and Eastern regions of Thailand. The members were taught soil testing with the
Table IV. Yield, profit and cost of maize production in the sitespecific nutrient management and in neighboring plots in Nakhon Ratchasima and Lop Buri provinces in 2004 (average of 8 farmers).

\begin{tabular}{lccc}
\hline Method & $\begin{array}{c}\text { Yield } \\
(\mathrm{kg} / \mathrm{ha})\end{array}$ & $\begin{array}{c}\text { Cost of production } \\
(\mathrm{US} \$ / \mathrm{T})\end{array}$ & $\begin{array}{c}\text { Profit } \\
(\mathrm{US} \$ / \mathrm{ha})\end{array}$ \\
\hline Farmer 1 & $5706 \mathrm{~b}$ & $83.8 \mathrm{a}$ & $165.3 \mathrm{~b}$ \\
Site-specific 2 & $9008 \mathrm{a}$ & $48.8 \mathrm{~b}$ & $547.2 \mathrm{a}$ \\
\hline
\end{tabular}

1 "Farmer" indicates fertilization according to farmer practice in a field adjacent to the site-specific nutrient management field.

2 "Site-specific" means the maize crop was fertilized according to sitespecific nutrient management technology.

Table V. Yield, cost of maize production and profit where sitespecific nutrient management was applied and the neighboring plots in Nakhon Ratchasima province in 2005 (average of 12 farmers).

\begin{tabular}{lccc}
\hline Method & $\begin{array}{c}\text { Yield } \\
(\mathrm{kg} / \mathrm{ha})\end{array}$ & $\begin{array}{c}\text { Cost of production } \\
(\mathrm{US} \$ / \mathrm{T})\end{array}$ & $\begin{array}{c}\text { Profit } \\
(\mathrm{US} \$ / \mathrm{ha})\end{array}$ \\
\hline Farmer 1 & $4061 \mathrm{~b}$ & $174.2 \mathrm{a}$ & $-201.6 \mathrm{~b}$ \\
Site-specific 2 & $7242 \mathrm{a}$ & $95.9 \mathrm{~b}$ & $206.2 \mathrm{a}$ \\
\hline
\end{tabular}

1 "Farmer" indicates fertilization according to farmer practice in a field adjacent to the site-specific nutrient management field.

2 "Site-specific" means the maize crop was fertilized according to sitespecific nutrient management technology.

soil test kit by the experienced farmer leaders, and also giving fertilizer recommendations by the farmers. In the case of rice and sugarcane farmers, there is also potential of forming a network. More farmers would like to join and learn about sitespecific nutrient management. The 53 farmers who carried out the initial demonstration plots for rice and sugarcane by sitespecific nutrient management have disseminated their information to about 120 farmers in Suphanburi province alone.

4. Knowledge of crop production. The farmer leaders learned from the field experiments about the rates of nutrients applied, and they could see the effect of over-application of nutrients. They requested information about beneficial insects and which are the pests, as well as information about plant diseases, soil improvement and the concept of site-specific fertilization. As a result of farmers gaining knowledge of soil amendments and fertilizers, there is reduced cheating with fake fertilizer and overpriced organic fertilizer by unscrupulous fertilizer marketers. The importance of soil improvement, which leads to lower fertilizer input and higher yields of sugarcane, was reported by the farmer leaders. Motivation to carry out soil improvement was seen among the farmers during the training course.

5. Health and environment. The farmer leaders report that the knowledge of appropriate use of chemical fertilizers and pesticides has resulted in the better health of the farmers. The additional benefit is the good environment. The significance of soil and water resources was also emphasized to encourage the farmers to realize and try to restore and maintain a healthy environment. 
Table VI. Rice yield and fertilizer cost of SSNM plots compared with no SSNM plots, 2005.

\begin{tabular}{|c|c|c|c|c|c|c|}
\hline Farmer & series & $\begin{array}{l}\text { Rec.fert. } \\
(\mathrm{kg} / \mathrm{ha})\end{array}$ & $\begin{array}{c}\text { Yield } \\
(\mathrm{kg} / \mathrm{ha}) \mathrm{SSNM}\end{array}$ & $\begin{array}{c}\text { Fertilizer cost (\$/ha) } \\
\text { SSNM }\end{array}$ & $\begin{array}{c}\text { Yield } \\
(\mathrm{kg} / \mathrm{ha}) \text { no SSNM }\end{array}$ & $\begin{array}{c}\text { Fertilizer cost (\$/ha) } \\
\text { no SSNM }\end{array}$ \\
\hline Manee & $\mathrm{Ph}$ & $50-25-38$ & 5881 & 66 & 3719 & 49 \\
\hline Patoom & Rs & $44-25-0$ & 6638 & 58 & 4250 & 86 \\
\hline Kasem & Bp & $25-25-0$ & 4244 & 33 & 4781 & 78 \\
\hline Boonyarit & Bp & $25-25-0$ & 4588 & 33 & 4087 & 60 \\
\hline
\end{tabular}

Table VII. Yield of sugarcane and fertilizer cost on SSNM plots compared with no SSNM plots, 2005. SSNM: site specific nutrient management.

\begin{tabular}{lcccccc}
\hline Farmer & Series & $\begin{array}{c}\text { Rec. Fert } \\
(\mathrm{kg} / \mathrm{ha})\end{array}$ & $\begin{array}{c}\text { Yield } \\
(\mathrm{T} / \mathrm{ha}) \text { SSNM }\end{array}$ & $\begin{array}{c}\text { Fertilizer cost (\$/ha) } \\
\text { SSNM }\end{array}$ & $\begin{array}{c}\text { Yield } \\
(\mathrm{T} / \mathrm{ha}) \text { no SSNM }\end{array}$ & $\begin{array}{c}\text { Fertilizer cost }(\$ / \text { ha }) \\
\text { no SSNM }\end{array}$ \\
\hline Vej & Msk & $0-50-25$ & 64.8 & 45 & 62.5 & 92 \\
Lawan & Msk & $38-25-50$ & 101.9 & 65 & 71.9 & 92 \\
Somyod & Msk & $94-50-94$ & 115.3 & 139 & 28.1 & 78 \\
Sombat & Pp & $94-75-94$ & 35.6 & 156 & 40.6 & 117 \\
Prachak & Pp & $63-25-0$ & 79.4 & 59 & 62.5 & 78 \\
Janesuk & Stuk & $0-25-50$ & 76.9 & 39 & & 117 \\
\hline
\end{tabular}

\subsection{Dissemination of the technology in 2003-2005}

The training in site-specific nutrient management of maize and empowerment of farmer leaders and officers was performed further during 2003-2005 with the support of the Department of Land Development (DLD) and SM-CRSP project. About 615 farmers and some 30 officers from 10 provinces were trained in the technology and empowerment techniques. The field tests were used as the demonstration sites for them to learn about the technology.

\subsection{Dissemination of the technology in 2005}

The dissemination of the technology by farmer leaders on maize was continued in 2005, although the project was terminated. Farmers were trained in bulk blending of fertilizers by the Bank of Cooperatives in the major provinces. The trained farmer leaders took part in presenting the lectures and thus reduced the cost of training. Soil testing by the soil test kit was included in the training package. This training course was the forum in which the trained farmer leaders took on a new task as not only leaders, but also trainers of new farmer leaders in the concepts of site-specific nutrient management.

During this year the inputs into crop production became much more expensive due to the continued increase in the cost of petroleum. The farmers who used site-specific nutrient management obtained a profit from maize production, although it was lower than in the previous year. In contrast, farmers who did not use site-specific nutrient management suffered a loss (Tab. V).

\section{RESEARCH AND DISSEMINATION OF THE TECHNOLOGY TO PADDY RICE AND SUGARCANE IN 2005-2007}

The site-specific nutrient management technology was extended to 5 provinces on rice and one province on sugarcane. The field tests and demonstration plots were used as learning sites of the farmer leaders under the supervision of the local officers in the respective provinces with the support of researchers of the current project. Using the techniques of farmer empowerment, 3 problems with the previous extension methodology were solved, that is, (1) we encouraged and supported the farmers to make their decisions and to assume their role as participants, not simply as laborers, as they were in the past. (2) Many problems in crop production were discussed and solved by the farmer leaders with our supervision. They learned to modify and adapt the package of knowledge themselves. (3) Not only was knowledge on site-specific nutrient management given, but also knowledge on insects, diseases and other useful information. The integrated knowledge for crop production with the participation of the farmers resulted in adopting the technology.

The results of the field tests showed the different response to nitrogen $(\mathrm{N})$ fertilizer in each location and the farmers compared the results with their previous crop production. They realized that the fertilizer application and other management were not efficient in the previous practice. In previous practice, higher amounts of fertilizer were applied but the yields were lower for both rice and sugarcane (Tabs. VI and VII).

In the case of rice production on Utt soil, the recommended SSNM treatment gave higher yield with a very low cost of fertilizer application. In contrast, the previous routine practice 
of the farmers resulted in lower rice yield but with a higher cost of production. The appropriate fertilizer application resulted in higher yield in most cases (Tab. VI).

In the case of sugarcane, it was noted that the soils were improved by incorporating green manure and filter cake, which resulted in higher sugarcane yield with lower amounts of chemical fertilizer. The differences in the yield in Pp soils of two farmers was an indication of the benefit of soil improvement. One farmer (Sombat) obtained lower yield and higher input due to burning of the sugarcane leaves in the field and no other soil improvement on Pp soil. The other farmer (Prachak, Pp soil) applied filter cake and got higher yield with lower fertilizer inputs (Tab. VI).

\section{CONCLUSION}

Site-specific nutrient management for farmers of small parcels was developed beginning with the adaptation to smallholder farmers from the concepts of Precision Agriculture beginning in 1997. The conceptual approach both simplified the technology and increased farmer capacity, and empowered the farmers to learn the technology and to become more selfreliant. The simplified technology included soil test kits, infield soil series identification and decision aids to simplify the making of site-specific fertilizer recommendations. Farmer leaders were identified and empowered. Farmer leaders and officers were trained and taught for 5 years in 15 provinces on maize, 5 provinces on rice and one province on sugarcane with the package of site-specific nutrient management technology. Building capacity of the farmer leaders by empowerment techniques resulted in a remarkable change and improvement in the farmers in terms of thinking and working. A better standard of living, greater initiative, new ideas and thought, and the formation of groups to share their resources and improvement and maintain their soil and water resources were seen. Farmer leaders not only learned effective fertilizer use and soil improvement but they also learned to assist other farmers to learn the techniques. Empowerment techniques had benefits far beyond those directly related to the site-specific nutrient management.

Acknowledgements: The authors would like to express their sincere thanks to the Thailand Research Fund, Department of Agricultural Extension of Thailand, Food and Agriculture Organization of the United Nations, Land Development Department of Thailand, and the Soil Management CRSP for financial support. Thanks are also due to K. Soitong, N. Wuttiwan and A. Chareonsaksiri, Department of Agricultural Extension, and S. Thirapon, Department of Agriculture, Ministry of Agriculture for their assistance in the training of the farmers and conducting the field experiments. Lastly, we would also like to thank the reviewers of an earlier draft of this manuscript for their helpful improvements.

\section{REFERENCES}

Attanandana T., Yost R.S. (2003) A site specific nutrient management approach for Maize: Thailand's experience, Better Crops International $17,3-7$.

Attanandana T., Yost R.S., Verapattananirund P. (2004) Adapting Site Specific Nutrient Management to Small Farms of the Tropics,
Proceedings of the Seventh Biannual Conference on Precision Agriculture, Minneapolis, Minnesota, July 25-28, 2004.

Attanandana T., Phonphoen A., Pinchongskuldit A., Yost R.S. (2006) SimCorn - A Software Designed to Support Site-Specific Nutrient Management For Farmers of Small Parcels in The Tropics, in: Zazueta J.X.F., Ninomiya S., Schiefer G. (Eds.), Computers in Agriculture and Natural Resources, American Society of Agricultural and Biological Engineers, Orlando, Florida.

Attanandana T., Yost R., Verapattananirund P. (2007) Empowering Farmer Leaders to Acquire and Practice Site- Specific Nutrient Management Technology, J. Sustain. Agr. 30, 87-104.

Colfer C. (1983) On communication among "unequals", Int. J. Intercultural Commun. 7, 263-283.

Department of Agriculture (Thailand) (2000) Fertilizer usage technology in rice field, Rice Research Center, Department of Agriculture, $124 \mathrm{p}$.

Department of Agriculture (Thailand) (2003) Statistics of chemical fertilizer import 2002, Database on chemical fertilizer import, year 2003.

Department of Agricultural Extension (2002) Strategic and crop development planning number 9 (2002-2006).

Department of Land Development (Thailand) (1991) Suitable soil management research report for rice, sugarcane, cassava, maize and pineapple.

Hart R. (2000) FSR - Understanding Farming Systems, in: Collinson M. (Ed.), A History of Farming Systems Research, CAB International, pp. 41-51.

Hildebrand P.E. (1979) Initial characterization - the rapid survey or Sondeo ICTA, Guatemala.

Khaosod newspaper (Thailand) (2002) Farmers go to Fertilizer Revolution Course, newspaper on May 26, 2002.

Korten D.C. (1980) Community organisation and rural development: a learning process approach, Public Administration Rev. 40, 480510.

KKU (1987) Proceedings of the 1985 Conference on Rapid Rural Appraisal, Khon Kaen, Khon Kaen University, Thailand.

Manager newspaper (Thailand) (2005) Newspaper on November 10, 2005.

Merrill-Sands D., Collion M.-H. (1994) Farmers and Researchers: The road to partnership, Agr. Human Values 11, 26-37.

Narayan D. (2007) Empowerment, J. Ambulatory Care Manag. 30, 120 125.

Norman D.W. (1980) Farming Systems Approach: relevance for the small farmer Michigan State University, Lansing, Michigan.

Office of Agricultural Economics (2002) Agricultural Statistics of Thailand, Crop year 2002/2003.

Rhoades R.E. (1982) The Art of the Informal Agricultural Survey International Potato Center, Lima, Peru. Royal Irrigation Department (2003) Irrigated area of Thailand.

Sajise P. (1981) Experimental education and its transfer: The Philippine Experience Education in ASEAN Universities, UNESCO, Kuala Lumpur, Malaysia.

Shaner W.W., Philipp P.F., Schmehl W.R. (1982) Farming Systems Research and Development: Guidelines for developing countries.

Smaling E.M.A., Braun A.R. (1996) Soil fertility research in Sub-Saharan Africa: New dimensions, new challenges, Commun. Soil Sci. Plan. $27,365-386$

Thairath newspaper (Thailand) (2002) Fertilizer revolution for cost production reduction, new formula, whose soils, whose recommendation, newspaper on July 1, 2002.

Yoshida S. (1981) Fundamentals of rice crop science, Int. Rice Res. Inst., Los Banos, Laguna, Philippines. 